\title{
Implementation of the REAP Strategy in the Aqidah Akhlak Course to Improve Student Literacy Ability
}

\section{Implementasi Strategi REAP Pada Mata Kuliah Aqidah Akhlak Untuk Meningkatkan Kemampuan Literasi Mahasiswa}

\author{
Dzulfikar Akbar Romadlon', Doni Septi², Budi Haryanto ${ }^{3}$ \\ ${ }^{1,2,3}$ Fakultas Agama Islam Universitas Muhammadiyah Sidoarjo \\ email:dzulfikarakbar@umsida.ac.id \\ email:donisepti79@gmail.com \\ email:budihar65@yahoo.co.id
}

Received: 30/07/2020, Accepted: 25/08/2020, Published: 29/08/2020

\begin{abstract}
Aqidah Akhlak is a course that must be attended by PAI students because they will become teachers who will teach this course. The Aqidah Akhlak teacher requires the ability of "information literacy" in the themes that are taught. In this study, the writer will implement the REAP strategy in The Aqidah Akhlak subject to improve the information literacy ability of college students. This research is a Classroom Action Research (CAR) and the subject of research is a PAI UMSIDA student. This research was conducted in several stages, namely planning, action, observation, and reflection. Data collection is done by observation, field notes, interviews, tests, and documentation. After conducting classroom action research on the Aqidah Akhlak course, the results obtained in the Pre-Assessment averaged 50.5, then increased in the Post-Assessment an average of 86.7. Improvement in each cycle is followed by an increase in students' ability to browse the literature appropriately and use it in argumentation, increased activity in discussions, and increased task completion. Based on these results it can be concluded that the implementation of REAP strategy can improve students' information literacy abilities.
\end{abstract}

Keywords: Aqidah Akhlak, Information Literacy, REAP Strategy

\begin{abstract}
ABSTRAK
Aqidah Akhlak merupakan mata kuliah yang harus diikuti oleh mahasiswa PAI, karena mereka akan menjadi guru yang akan mengajarkan materi ini. Guru Aqidah Akhlak memerlukan kemampuan "literasi informasi" dalam tema-tema yang diajarkannya. Pada penelitian ini, penulis akan mengimplementasikan strategi REAP pada mata kuliah Aqidah Akhlak untuk meningkatkan kemampuan literasi informasi mahasiswa calon guru. Penelitian ini merupakan Penelitian Tindakan Kelas (PTK) atau classroom action research dan subjeknya adalah mahasiswa PAI UMSIDA. Penelitian ini dilakukan dalam beberapa tahap, yaitu perencanaan, tindakan, pengamatan, dan refleksi. Pengumpulan data dilakukan dengan observasi, catatan lapangan, wawancara, tes, dan dokumentasi. Setelah dilakukan penelitian tindakan kelas pada mata kuliah Aqidah Akhlak, hasil yang didapatkan dalam Pre-Assessment rata-rata sebesar 50.5, kemudian meningkat pada Post-Assessment rata-rata sebesar 86.7, peningkatan di setiap siklus diikuti dengan meningkatnya kemampuan mahasiswa dalam menelusuri literatur dengan tepat dan menggunakannya dalam berargumentasi, meningkatnya keaktifan dalam diskusi, dan meningkatnya penyelesaian tugas. Berdasarkan hasil ini dapat disimpulkan bahwa penerapan strategi REAP dapat meningkatkan kemampuan literasi informasi mahasiswa.
\end{abstract}

Kata kunci: Aqidah Akhlak, Literasi Informasi, Strategi REAP 


\section{PENDAHULUAN}

Aqidah Akhlak adalah salah satu mata kuliah yang harus diampu oleh mahasiswa Pendidikan Agama Islam (PAI) di Universitas Muhammadiyah Sidoarjo (UMSIDA). Materi “Aqidah" dan "Akhlak" sebenarnya merupakan dua disiplin ilmu yang berbeda. Aqidah berkaitan dengan keyakinan yang ada dalam diri, sedangkan Akhlak lebih berkaitan dengan buah karakter, perbuatan, sikap, atau etika dari aqidah tersebut (Nurhayati 2014). Namun melihat relasi antara keduanya maka materi ini digabungkan menjadi "Aqidah Akhlak" dan diajarkan mulai ditingkat sekolah hingga perguruan tinggi.

Mata kuliah Aqidah Akhlak harus diikuti oleh mahasiswa PAI UMSIDA sebanyak 2 SKS, karena mereka adalah calon guru yang nantinya akan mengajarkan materi ini ditingkat MI, MTS, atau MA, atau yang sederajat. Maka untuk dapat menjadi guru Aqidah Akhlak, setiap calon guru perlu menguasai materi tersebut secara mendalam. Hal ini penting, karena mengajarkan materi ini membutuhkan kemampuan nalar yang logis dan kritis. Karena ketika calon guru nanti mengajarkan materi tersebut mereka akan menemukan pertanyaan-pertanyaan dari siswa yang kritis. Misalkan jika murid bertanya: "apakah bukti akan adanya
Tuhan?" Tema ini berkaitan dengan masalah aqidah yang sangat mendasar. Jika guru tidak memiliki penguasaan materi yang cukup, dapat dimungkinkan kegagalan pembelajaran Aqidah Akhlak dan dapat menyebabkan pemahaman yang salah. Maka, semua calon guru PAI dituntut harus mampu menguasai berbagai permasalahan dalam materi tersebut secara logis dan ilmiah.

Agar calon guru mampu menjadi guru yang kompeten maka mereka memerlukan kemampuan "literasi informasi" terkait dengan tema-tema yang ada dalam Aqidah Akhlak. Literasi informasi yang dimaksud adalah keahlian dalam mengakses dan mengevaluasi informasi secara efektif untuk memecahkan masalah dan membuat keputusan. Dengan memiliki kemampuan ini seseorang dapat mudah untuk belajar, karena mereka mampu untuk mengelola informasi, mengevaluasi, memilah-milah, dan menggunakannya. Atau dapat disimpulkan bahwa kemampuan literasi informasi adalah kemampuan untuk berfikir melalui berbagai sumber literatur.

Calon guru membutuhkan kemampuan ini, karena hampir seluruh materi yang diajarkan dalam Aqidah Akhlak bersifat teoritis. Sehingga dalam materi buku teks yang digunakan, selalu 
berisi konsep-konsep yang harus dibaca dengan nalar yang kritis dan dicari perbandingannya melalui sumber-sumber informasi lain baik yang ada di perpustakaan, internet, maupun media massa. Oleh karenanya dibutuhkan sebuah strategi pembelajaran yang membantu calon guru dalam memahami teks bahan ajar yang menumbuhkan kemampuan berfikir kritis (Pattah 2014).

Maka pada penelitian ini, penulis mencoba menerapkan strategi REAP dalam pembelajaran Aqidah Akhlak. Tujuannya agar mahasiswa mampu meningkatkan kemampuan literasi informasi dalam mata kuliah Aqidah Akhlak.

\section{TINJAUAN PUSTAKA}

\subsection{Pembelajaran Aqidah Akhlak}

Pembelajaran Aqidah harus dilakukan dengan strategi yang tepat, karena jika tidak sesuai dapat menimbulkan kesesatan. Kelompok Mu'tazilah mewajibkan semua orang, termasuk orang awam, untuk mengetahui berbagai perdebatan dalam hal aqidah yang menjadi objek Ilmu Kalam (Jabbar 1996). Menurut Imam Al-Ghazali hal ini tidak dapat dibenarkan, karena orang awam jika bertemu dengan ilmu kalam, mereka akan kebingungan. Namun, Imam Al-Ghazali tidak mengharamkan Ilmu Kalam, karena hal itu berguna untuk menjaga Aqidah Islam dari berbagai tantangan baik tantangan dari kelompok ahli bid'ah, atau tantangan eksternal yang datang dari luar Islam (Al-Ghazali 2005).

Imam Al-Ghazali memberikan sebuah metode bagi anak kecil dan bagi orang awam, dalam mempelajari aqidah, cukup baginya diberikan penguatan dengan strategi penyampaian menggunakan ayat Al-Qur'an dan Hadith, dicampur dengan seni dalam menyampaikan. Sedangkan Ilmu Kalam, hanya boleh diajarkan kepada orang yang memiliki kualifikasi keilmuan. Bagi pelajar Ilmu Kalam harus didasari dengan aqidah dan metodologi keilmuan yang benar, sehingga mampu menjadi benteng pertahanan bagi aqidah Islam (AlGhazali 2005).

Untuk tingkat Perguruan Tinggi pengembangan kemampuan thingking skill adalah suatu keniscayaan. Sehingga harus dimasukkan beberapa materi Ilmu Kalam dan Filsafat dalam pembelajaran Aqidah agar ia mampu untuk memberikan argumentasi terhadap Aqidah Islam yang diyakininya. Walaupun materi yang diajarkan harus selalu berada pada bimbingan guru, agar tidak tersesat sebagaimana yang dikhawatirkan Imam AlGhazali. 
Dengan penanaman Aqidah diharapkan mampu memunculkan Akhlak yang baik. Karena setiap bentuk keyakinan yang ada dalam rukun iman memiliki implikasi etis dalam diri manusia. Sehingga Aqidah Islam yang diyakini oleh setiap individu harus menghasilkan akhlaq yang timbul dalam perbuatan. Oleh karenanya guru materi Aqidah Akhlak harus mampu memunculkan relasi ini dalam setiap pembelajarannya sehingga materi Aqidah Akhlak mampu memunculkan karakter yang baik dalam diri siswa (Ginanjar and Kurniawati 2017).

\subsection{Literasi Informasi}

Literasi informasi merupakan serangkaian kemampuan yang dibutuhkan bagi seseorang untuk mengenali kapan sebuah informasi itu dibutuhkan, juga kemampuan untuk menempatkan, mengevaluasi, dan menggunakan secara efektif sebuah informasi. Oleh karenanya literasi informasi membutuhkan: 1. Penggunaan teknologi, 2. Penggunaan sumber informasi, 3. Mengelola sebuah proses, 4. Mengontrol penggunaan informasi, 5. Memperoleh pengetahuan 6 . Mengembangkan pengetahuan, dan 7 . Memperoleh kebijaksanaan. Pada tataran ini dengan memiliki kemampuan literasi informasi seseorang mampu dengan bijak mengelola pengetahuan yang berasal dari berbagai sumber, dan ini adalah definisi kebijaksanaan atau wisdom (Setyowati 2015).

Kemampuan literasi informasi penting untuk dimiliki oleh mahasiswa karena hal itu akan mengembangkan nilai dari perguruan tinggi. Tujuan dari pengembangan literasi informasi di perguruan tinggi agar: Menciptakan mahasiswa yang mampu berfikir kritis, mengevaluasi informasi, menggunakan informasi yang relevan dengan lebih efisien dan efektif, serta terhindar dari plagiarisme (Ganggi 2017). Maka untuk menciptakan kemampuan literasi informasi di tingkat perguruan tinggi perlu strategi dan Strategi pembelajaran yang memunculkan kemampuan berfikir kritis dan mampu mengolah data, diantaranya adalah Strategi REAP.

\subsection{Strategi Reading, Encoding,} Annotating, Pondering (REAP)

Untuk memunculkan critical thingking diperlukan Strategi yang cocok untuk digunakan dalam pembelajaran, diantaranya adalah Strategi REAP yang dirumuskan oleh Anthony Manzo. Strategi ini dibagi kedalam 4 tahapan: Pertama, Reading atau membaca teks untuk mengetahui pesan-pesan inti dari teks; Kedua, Encoding atau teks yang sudah 
dibaca ditulis ulang menggunakan bahasanya sendiri; Ketiga, Annotating atau memberi keterangan teks yang sudah ditulis dan mengaitkannya dengan sumber lainnya, atau dengan sudut pandang lainnya; Keempat, Pondering atau mendiskusikan teks yang sudah dianalisa kepada orang lain dan meminta respon mereka, kemudian membaca respon tersebut. Berdasarkan 4 tahapan ini, guru akan mengembangkan kemampuan berfikir siswa dari proses berfikir pasif menjadi proses berfikir aktif (Anthony V. Manzo 1985).

Manzo dalam blognya menyebutkan bahwa tujuan dari REAP adalah untuk menciptakan pola pikir dari perspektif yang berbeda. Siswa seringkali tidak membaca teks dengan kritis. Dengan menggunakan REAP membuat mereka untuk kembali memeriksa informasi dan fakta-fakta yang ada dalam tulisan sebelum ia melangkah terlalu jauh yang mungkin akan menimbulkan kesalahpahaman. Kemudian siswa diharuskan menulis sebagai respons dari membaca, hal ini menanamkan kepekaan yang lebih besar pada mereka, khususnya ketika mereka mendiskusikan pemikiran mereka dengan orang lain. Dengan adanya respons terhadap teks hal ini sangat kondusif untuk menciptakan pembelajaran yang lebih aktif (U. Manzo and Manzo 2010).
Pemikiran kritis ditumbuhkan khususnya pada tahap annotating dan pondering. Di tahap annotating siswa mengomentari teks tersebut dengan menguji berbagai argumentasi yang ada dalam teks dan memikirkan apakah yang ditulis itu masuk akal atau tidak. Untuk mengatakan masuk akal mereka dituntut untuk membandingkan dari teks yang dibaca dengan teks-teks lain, sehingga memacunya untuk menganalisa ide pokok teks sehingga mahasiswa akan terbuka terhadap berbagai spektrum pemikiran.(A. Manzo, Manzo, and Albee 2002) Di tahap pondering siswa mendiskusikan hasil pembahasannya dengan orang lain agar ia mampu meluaskan lebih jauh lagi cara pandangnya dan pemikirannya. Selain itu tahap ini juga berfungsi untuk memfalsifikasi pendapat yang sudah diyakininya setelah melakukan penelusuran melalui berbagai sumber, apakah argumentasi dari pendapat yang mereka yakini mampu dipertahankan ataukah tidak? Dengan demikian, mahasiswa mampu mempertimbangkan lebih jauh kekuatan dari argumentasi dan pendapatnya.

Maka dalam pembelajaran Aqidah Akhlak diperlukan strategi dan metode pembelajaran yang sesuai untuk menumbuhkan kemampuan literasi 
informasi. Di antara strategi yang dapat diterapkan adalah strategi reading, encoding, annotating, dan pondering (REAP), yaitu strategi yang sering digunakan untuk menumbuhkan skill berfikir yang kritis. Strategi REAP dapat digunakan baik untuk siswa sekolah dasar hingga menengah. Dalam penelitian Andarini dan Ali terhadap tiga sekolah dasar di Jogjakarta dicapai hasil bahwa strategi REAP memberikan efek yang signifikan dan positif terhadap pemahaman bacaan siswa kelas 5 sekolah dasar (Cahyaningtyas and Mustadi 2018). Juga penelitian Sukma dan Haryadi tentang penerapan strategi REAP dan Request untuk anak SMP dicapai hasil bahwa strategi REAP lebih efektif dibandingkan strategi tradisional dan strategi Request (Sukma and Haryadi 2016). Juga pada penelitian Fera Zasrianita tentang penerapan REAP dalam pelajaran Reading (memahami teks bahasa Inggris) untuk anak MTS disimpulkan bahwa REAP membantu siswa dalam memahami teks-teks berbahasa Inggris (Zasrianita 2016). Juga kesimpulan oleh Rutela Renette, bahwa strategi ini memiliki keuntungan di setiap langkahnya untuk membantu siswa dalam memahami teks (Renette 2016). Namun dari penelitianpenelitian di atas hanya terfokus pada peningkatan siswa dalam memahami teks- teks Bahasa Inggris, belum pada pengembangan kemampuan berfikir.

\section{METODE}

Jenis penelitian ini adalah penelitian kualitatif, berupa penelitian tindakan kelas atau classroom action research (CAR). Penelitian ini terdiri dari 2 siklus, di setiap siklusnya terdiri dari perencanaan, pelaksanaan, pengamatan, dan refleksi dengan tema Iman kepada Allah. Dalam perencanaan: Peneliti merumuskan masalah yang dihadapi mahasiswa dan mencari upaya peningkatan kemampuan literasi mahasiswa PAI melalui strategi REAP. Implementasi: Pada penelitian ini dilakukan tindakan dalam pembelajaran mata kuliah Aqidah Akhlak menggunakan strategi REAP untuk meningkatkan kemamapuan literasi informasi mahasiswa PAI. Observasi: dilakukan dalam dua tahapan, yaitu Observasi proses dan observasi hasil. Observasi proses meliputi proses perkuliahan. Sedangkan observasi hasil berupa pertanyaan apakah kemampuan literasi informasi mahasiswa dapat meningkat sebelum dan setelah mengikuti perkuliahan yang menggunakan strategi REAP? Refleksi: dilakukan untuk mengetahui kelebihan dan kelemahan strategi REAP yang digunakan pada perkuliahan Aqidah Akhlak. Hal ini 
dilakukan untuk memperoleh perbaikan dari hal yag kurang baik. hasil dari refleksi digunakan sebagai panduan untuk menyusun solusi untuk silkus yang berikutnya.

Data yang diperoleh dalam penelitian ini berupa kualitatif dan kuantitatif. Data kualitatif berupa deskripsi hasil observasi, catatan lapangan, dan analisis hasil wawancara. Sedangkan data kuantitatif berupa hasil tes belajar mahasiswa yang beruka skor tes. Skor tersebut dihitung pada setiap siklusnya dan dibandingkan dengan siklus sebelumnya. Kemudain data-data itu dianalisis menggunakan teknik yang mengacu pada Miles and Huberman (Milles, Huberman, and Saldana 2014) yang terdiri dari tiga alur kegiatan, yaitu reduksi data, penyajian data, dan penarikan kesimpulan. Pertama, kegiatan reduksi data dilakukan dengan memusatkan perhatian, penyederhanaan, serta mentransformasi data "kasar" yang berasal dari catatan lapangan dari hasil observasi dan wawancara. Kedua, kegiatan penyajian data dilakukan dengan menyajikan data dengan bentuk teks naratif, yaitu teks dalam bentuk catatan hasil wawancara sebagai informasi tersusun yang memungkinkan untuk menarik kesimpulan. Ketiga, pada kegiatan penarikan kesimpulan, peneliti menarik kesimpulan yang berasal dari data-data yang telah terkumpul.

\section{HASIL PEMBAHASAN}

\subsection{Implementasi Strategi REAP dalam} Pembelajaran Aqidah Akhlaq

Untuk mengimplementasikan strategi ini pertama peneliti menawarkan sebuah modul teks yang berisi tentang berbagai masalah terkait "Iman kepada Allah", diambil melalui berbagai sumber internet. Tema yang didiskusikan antara lain: wujud Allah, sifat Allah, keesaan Allah, ilmu Allah, dan konsep penciptaan. Karena terdiri dari 5 tema maka mahasiswa dibagi menjadi kedalam 5 kelompok, setiap kelompok terdiri dari 6-7 orang. Setiap mahasiswa dalam kelompok tersebut mendapatkan satu sub-tema dari tema umum untuk melakukan kegiatan pembelajaran dan diskusi.

Metode REAP yang dilakukan kepada mahasiswa tidak cukup jika dilakukan selama 1 pertemuan saja. Oleh karenanya peneliti membagi kegiatan itu kedalam 3 kali pertemuan di setiap siklusnya. 1. Pelaksanakan reading dan encoding, 2. Pelaksanakan Annotating, 3. Pelaksanaan pondering.

Pada tahap reading mahasiswa membaca teks tersebut dan memahami 
pemikiran umum dari teks tersebut. Dalam teks itu mahasiswa membaca pemikiran, konsep, dan teori dari berbagai madhab dalam Islam terkait tema tersebut secara ringkas. Kegiatan ini dilakukan selama 30 menit karena ada beberapa konsep yang diperlukan pemahaman mendalam dalam memahaminya.

Tahap encoding dilakukan selama 30 menit berikutnya, yakni ketika mahasiswa menuliskan ulang pemahamannya dengan bahasanya sendiri berbeda dari teks asalnya. 30 menit berikutnya mereka menyampaikan pemahaman itu dalam sebuah forum diskusi perkelompok. Ketika mereka mampu menuliskan ulang dan menyampaikan argumentasi yang ada, maka pasti mereka sudah mampu memahami kandungan teks.

Pada pertemuan ke-dua, di tahap annotating lebih banyak bersifat penugasan agar mahasiswa menulis sebuah komentar yang disusun dalam artikel sederhana. Dan untuk memunculkan pemikiran yang analitis dan kritis terhadap teks mahasiswa perlu melakukan mahasiswa perlu belajar 4 model annotating sebagaimana yang dijelaskan oleh Manzo (Anthony V. Manzo 1985) sebagai berikut: (ditambah dengan contoh yang diambil dari masalah-masalah Aqidah)
Thesis annotation, yaitu memberikan statement yang tajam sampai ke ide pokok dari suatu artikel atau buku. Statemen tersebut harus berdasarkan logika yang benar dan tersambungkan antara satu pernyataan kepernyataan lainnya. Misalkan: "Bagi Mu'tazilah kalam Allah itu diciptakan (makhluq). Namun jika kalam itu makhluq, sebelum ia diciptakan berarti Allah itu bisu (abkam)."

The probe annotation atau catatan penyelidikan dan pengujian, yaitu fokus pada melakukan pertanyaan-pertanyaan, penelusuran point dan argumentasi sehingga sebuah kesimpulan dan putusan dapat dicapai. Pertenyaan-pertanyaan itu berfungsi untuk memverifikasi konsekwensi dan alternatif dari teks. Misalkan: “Mengapa Mu'tazilah mengatakan bahwa kalam Allah itu makhluq? Apa konsekuensinya jika kalam Allah itu qidam (kekal)? Apakah ada cara untuk menyelesaikan dilema antara kalam Allah itu makhluq atau qidam?

Personal view annotation, catatan ini untuk menjawab bagaimana pengalaman seseorang dalam melihat dan perasaan melawan ide pokok dari suatu teks. Misalkan: "Mengapa banyak ulama' yang dipenjara, disiksa, bahkan dieksekusi pada masa Bani Abbasiyyah yang bermadhab Mu'tazilah, hanya karena tidak mau 
mengatakan bahwa kalam Allah. Padahal ini adalah salah satu masalah kecil dalam Aqidah Islam. Saya menyimpulkan bahwa ketika sebuah kekuasaan berdasarkan suatu ideologi tidak boleh memaksakan ideologinya kepada masyarakat yang berpandangan lain, karena hanya akan menciptakan kekerasan.”

Inventive annotation atau catatan dengan sengaja difungsikan untuk membangun cara pandang dengan melihatnya dari konteks yang lain atau dengan mensintesiskan berbagai pendapat. Sebagai contoh: "Dua cara pandang antara kalam Allah sebagai qidam atau makhluq, memiliki argumentasi yang kuat dan samasama memiliki kelemahan jika ditinjau dari beberapa perspektif. Maka kita perlu keluar dari perdebatan ini dan melihat dari cara pandang lain. Bahwa keimanan kepada sifat Allah itu wajib dan tidak selayaknya kita memperdebatkan kedua hal itu, apalagi jika menciptakan suatu kekerasan atau mengkafirkan sesama muslim.”

Selama seminggu mahasiswa harus mampu melakukan penulisan komentar berdasarkan 4 model komentar ini dan penelusuran melalui sumber-sumber lain baik untuk mendukung ataupun menolak dari tema yang diberikan. Di pertemuan berikutnya dilakukan tahap pondering, yaitu kegiatan menimbang ulang ide dan konsep yang dimilikinya dengan cara mendiskusikan kepada kawan-kawannya. Selama 45 menit setiap mahasiswa memaparkan argumentasi dan pendapatnya, kemudian mahasiswa lainnnya memberikan pendapat, masukkan, ataupun kritikan. Semua kegiatan diskusi itu dinotuensikan oleh satu orang kemudian dalam 45 menit lainnya setiap kelompok memaparkan hasil diskusinya dalam kelas, kemudian setiap kelompok memberikan komentar terhadap hasil diskusi tersebut.

\subsection{Hasil Pre-Assessment}

Objek penelitian berisi mahasiswa Pendidikan Agama Islam (PAI) Universitas Muhammadiyah Sidoarjo semester 4 dengan jumlah 32 mahasiswa. Setelah dilakukan Pre-Assessment kepada mereka, pada tanggal 21 February 2020 melalui pertanyaan-pertanyaan terkait dengan tema "Iman kepada Allah" yang berupa pertanyaan essay, ditemukan hasil rata-rata 50.5 , dengan perincian sebagai berikut:

\begin{tabular}{|c|c|c|c|c|}
\hline No & Score & Kategori & Frekuensi & Persen \\
\hline
\end{tabular}




\begin{tabular}{ccccc}
\hline 1 & $86-100$ & Sangat Baik & - & \\
\hline 2 & $71-85$ & Baik & 6 & $18.75 \%$ \\
\hline 3 & $61-70$ & Sedang & 16 & $50 \%$ \\
\hline 4 & $0-60$ & Kurang & 10 & $31.25 \%$ \\
\hline
\end{tabular}

Tabel 1: Pre-Assessment

Dari hasil ini ditemukan bahwa belum ada mahasiswa yang mampu mengutarakan argumentasi dengan sangat baik dalam pilihan essay. Sedangkan yang mampu mengutarakan argumentasi dengan baik $18.75 \%$, cukup 50\%, dan kurang $31.25 \%$. Dari hasil pre-test ini penulis melihat bahwa mereka belum mampu memberikan argumentasi logis terhadap pertanyaan-pertanyaan yang diberikan. Kemudian mereka belum memiliki kemampuan literasi informasi terhadap tema iman kepada Allah hal ini ditandai masih belum ada dari mereka yang menyebutkan sumber rujukan yang digunakan.

\subsection{Deskripsi Siklus 1}

Setelah melihat nilai pre-test maka kemudian peneliti mempersiapkan teks-teks yang berisi argumentasi terkait dengan materi ke-imanan kepada Allah. Pada materi ini terdapat 6 tema diantaranya adalah wujud Allah, sifat Allah, ilmu Allah, konsep penciptaan, qudrah dan iradah
Allah, dan kalam Allah. Teks yang dipilihkan bukan hanya berisi deskripsi saja, namun juga berisi argumentasi analitis dan kritis terhadap tema-tema tersebut. Sehingga memungkinkan bagi mahasiswa untuk mencari sumber lain melalui jurnal, internet, dan buku. Pada siklus ini terdiri dari 4 tahap:

Pada tahap perencanaan peneliti mempersiapkan silabus, RPP, bahan ajar, teknik pembelajaran, pengaturan kelas, soal-soal, dan dokumen ceklis untuk mengobservasi dosen dalam pengajarannya dan mahasiswa dalam kegiatan belajar.

Pada tahap pelaksanaan mahasiswa dibagi kedalam 6 kelompok merepresentasikan 6 tema yang dibahas. Di setiap kelompok terdiri dari 5-6 mahasiswa. Pertemuan pertama dilaksanakan tanggal 28 Februari 2020. Pada tahap ini ditemukan mahasiswa masih banyak yang belum mengetahui wacana yang dipaparkan dalam teks. Kemudian dalam tahap ini mereka mulai mampu melakukan encoding 
terhadap teks dan mampu menyampaikan hasil pemahaman mereka dalam forum diskusi.

Pada pertemuan berikutnya tanggal 3 Maret 2020, mahasiswa diajari bagaimana melakukan annatoting terhadap teks dan melakukan sebuah penelusuran literasi melalui berbagai sumber untuk mendapatkan hasil yang lebih valid terkait hasil bacaannya. Untuk meyakinkan bahwa mereka sudah melakukan annotating, maka mereka harus menuliskannya kedalam sebuah artikel singkat yang berisi kesemua model annotating. Kemudian mahasiswa dalam menulis artikel juga diwajibkan membandingkan dan mengambil rujukan dari referensi lain baik melalui jurnal, buku, maupun internet. Waktu penulisan artikel terakhir hingga tanggal 6 Maret 2020. Pada tanggal 6 Maret 2020, mahasiswa melakukan diskusi terhadap hasil bacaannya kemudian hasilnya disampaikan dalam forum kelas.

Pada tanggal 8 Maret 2020 peneliti melakukan test kompetensi berupa essay kepada mahasiswa menggunakan sistem daring. Test ini berupa pertanyaanpertanyaan yang mengharuskan mahasiswa menuliskan argumentasi yang bersandarkan pada pendapat, ungkapan, maupun bukti dari sumber-sumber yang ada. Dengan test itu didapatkan hasil nilai rata-rata seluruhnya 73.4 meningkat dari sebelumnya dengan rata-rata kelas 50.5, dengan perincian sebagai berikut:

\begin{tabular}{ccccc}
\hline No & Score & Kategori & Frekuensi & Persen \\
\hline 1 & $86-100$ & Sangat Baik & 2 & $6.50 \%$ \\
\hline 2 & $71-85$ & Baik & 9 & $28.12 \%$ \\
\hline 3 & $61-70$ & Sedang & 14 & $43.75 \%$ \\
\hline 4 & $0-60$ & Kurang & 7 & $21.88 \%$ \\
\hline
\end{tabular}

Tabel 2: Assessment Siklus 1

Jikalau sebelumnya mahasiswa yang mendapatkan nilai sangat baik adalah $0 \%$ pada siklus 1 meningkat menjadi $6.5 \%$. Sedangkan sisanya berada pada kategori baik $28.12 \%$ dan sedang $43.75 \%$. Kemudian pada kategori kurang pada preassessment terdapat $31.25 \%$ sedangkan pada siklus 1 sudah berkurang menjadi 
21.88\%. Dengan hasil ini dipastikan bahwa terjadi peningkatan kemampuan mahasiswa PAI dalam memahami materi Iman kepada Allah

Pada tahap pengamatan peneliti meminta observer untuk melakukan pengamatan terhadap setiap kegiatan pembelajaran yang terjadi, seperti: performa peneliti, respon mahasiswa dalam kegiatan pembelajaran, dan keadaan kelas. Observasi dilakukan checklist berisi observasi untuk mahasiswa dan observasi untuk dosen. Berdasarkan observasi strategi REAP mampu memunculkan model pembelajaran student center learning (SCL) karena mahasiswa dituntut aktif untuk mencari dan menemukan materi sendiri baik melalui artikel yang ada di internet atau melalui jurnal ilmiah.

Berdasarkan hasil observasi, ditemukan bahwa dengan digunakannya strategi REAP muncul keaktifan mahasiswa dalam kegiatan pembelajaran, baik ketika memberikan pertanyaan, berdiskusi, dan memberikan tanggapan, walaupun belum seluruh mahasiswa mampu aktif dalam pembelajaran.

Pada tahap refleksi, peneliti berdiskusi dengan observer tentang pelaksanaan pada siklus pertama. Hasil dari pelaksanaan strategi REAP menunjukkan bahwa skor mahasiswa pada siklus 1 lebih baik dari nilai Pre-Assessment, namun masih ada 7 mahasiswa yang masih belum mencapai nilai minimal. Setelah melakukan diskusi dengan observer ditemukan beberapa masalah sehingga perlu untuk dilakukan siklus kedua, diantaranya: kurangnya kemampuan beberapa mahasiswa untuk mengikuti alur logika dari teks, kurangnya kemampuan untuk menelusuri sumber lain, kurangnya dalam menyampaikan argumentasi, dan kurangnya keberanian sebagaian mahasiswa dalam berdiskusi, hal ini menunjukkan bahwa kemampuan infomasi literasi sebagaian mahasiswa masih kurang.

\subsection{Deskripsi Siklus 2}

Setelah dilakukan analisa dan evaluasi terhadap proses pembelajaran yang dilakukan pada siklus pertama, peneliti kemudian merencanakan proses pembelajaran pada siklus kedua. Dalam merencanakan siklus kedua peneliti melakukan identifikasi terhadap masalahmasalah yang berkembang di siklus pertama. Pada siklus pertama masih ada 7 orang yang belum mampu mencapai nilai minimal. Kemudian ada kekurangankekurangan dari sebagian mahasiswa yang masih belum mampu menyampaikan argumentasi dengan baik. Sehingga hal ini mendorong kepada peneliti untuk 
menciptakan inovasi-inovasi baru baik dalam metode mengajar maupun materi pembelajaran sehingga mampu memperbaiki kekurangan yang ada dan memunculkan antusias mahasiswa dalam belajar.

Pada siklus kedua peneliti akan menyisipkan pada tahap reading, beberapa penjelasan tentang argumentasi dan istilah yang sulit untuk dipahami. Agar mahasiswa sebelum masuk kelangkah berikutnya sudah memiliki pemahaman yang lebih menyeluruh terhadap teks.

Sebagaimana tahap sebelumnya mahasiswa dibagi kedalam 6 kelompok untuk merepresentasikan 6 tema yang dibahas. Di setiap kelompok terdiri dari 5-6 mahasiswa. namun yang menjadi perbedaan dengan siklus sebelumnya peneliti merubah topik kajian dari setiap orang namun masih dalam satu tema yang sama.

Pada pertemuan pertama dilaksanakan tanggal 10 Maret 2020. Pada tahap ini mahasiswa membaca teks selama 45 menit dan di sela-sela proses reading dosen akan menjelaskan berbagai ungkapan dan istilah, jika mahasiswa mengalami kesulitan. Pada pertemuan ini terrekam beberapa kalimat yang belum bisa dipahami mahasiswa khususnya pada argumentasi filosof muslim dan ahli kalam. Pada 30 menit berikutnya mereka melakukan encoding, kemudian mendiskusikan hasil bacaannya selama 15 menit kepada kawannya. Kemudian di akhir sesi mahasiswa sudah diminta untuk menulis artikel dengan menggunakan berbagai jenis annotating yang telah mereka pelajari dengan ketentuan seperti di siklus pertama.

Pada tanggal 13 Maret 2020, mahasiswa melakukan diskusi terhadap hasil bacaannya selama 30 menit kemudian hasilnya disampaikan dalam forum kelas. Kemudian setiap kelompok diwajibkan untuk memberikan komentar, sanggahan, atau masukkan hal ini kemudian akan dikomentari oleh dosen sebagai penengah.

Pada tanggal 15 Maret 2020 dilakukan test kompetensi berupa test essay kepada mahasiswa menggunakan sistem daring. Test itu dilakukan untuk mengetahui peningkatan kemampuan mahasiswa. Nilai rata-rata yang dicapai 82.6 meningkat dari sebelumnya dengan rata-rata kelas 73.4, dengan perincian sebagai berikut:

\begin{tabular}{ccccc}
\hline No & Score & Kategori & Frekuensi & Persen \\
\hline 1 & $86-100$ & Sangat Baik & 5 & $15.63 \%$ \\
\hline
\end{tabular}




\begin{tabular}{ccccc}
\hline 2 & $71-85$ & Baik & 15 & $46.87 \%$ \\
\hline 3 & $61-70$ & Sedang & 12 & $37.5 \%$ \\
\hline 4 & $0-60$ & Kurang & - & $0 \%$ \\
\hline
\end{tabular}

Tabel 3: Assessment Siklus 2

Jikalau sebelumnya mahasiswa yang mendapatkan nilai sangat baik adalah $6.5 \%$ pada siklus 1 meningkat menjadi $15.63 \%$. Sedangkan sisanya berada pada kategori baik $46.87 \%$ dan sedang $37.5 \%$. Kemudian pada kategori kurang pada siklus 1 sejumlah $21.88 \%$ pada siklus 2 berada pada $0 \%$. Dengan demikian di siklus 2 telah terjadi peningkatan kemampuan literasi informasi mahasiswa PAI setelah dilakukan strategi REAP dalam pembelajaran

Hasil observasi juga ditemukan bahwa dengan digunakannya strategi REAP terjadi peningkatan terhadap antusias mahasiswa jauh melebihi pada siklus pertama. Peningkatan itu terlihat dalam 3 hal: Pertama, peningkatan kemampuan mahasiswa dalam mengemukakan argumentasi dengan baik berdasarkan penelusuran sumber-sumber lain dari internet, buku, dan artikel sesuai dengan tema yang ia bahas. Kedua, peningkatan mahasiswa untuk melakukan feedback dalam forum diskusi, baik ketika diskusi dalam kelompok dan diskusi dalam lingkup kelas. Ketiga, peningkatan mahasiswa dalam mengerjakan tugas-tugas yang diberikan.

Dalam tahap refleksi disimpulkan bahwa mahasiswa sudah mampu menelusuri jawaban-jawaban argumentatif dari masalah-masalah Iman kepada Allah yang diberikan, melalui penelusuran berbagai sumber baik internet, jurnal maupun buku-buku.

\subsection{Penjelasan Post-Assessment}

Pada tanggal 17 Maret 2020 dilaksanakan post-assessment untuk memastikan peningkatan yang terjadi setelah dilaksanakannya siklus 1 dan siklus 2. Soal yang diberikan berisi 10 soal essay yang sama dengan soal ketika preassessment. Hasil yang diperoleh sebagaimana dalam tabel berikut:

\begin{tabular}{|c|c|c|c|c|}
\hline No & Score & Kategori & Frekuensi & Persen \\
\hline
\end{tabular}




\begin{tabular}{ccccc}
\hline 1 & $86-100$ & Sangat Baik & 9 & $28.13 \%$ \\
\hline 2 & $71-85$ & Baik & 17 & $53.12 \%$ \\
\hline 3 & $61-70$ & Sedang & 6 & $18.75 \%$ \\
\hline 4 & $0-60$ & Kurang & - & $0 \%$ \\
\hline
\end{tabular}

Tabel 4: Post-Assessment

Berdasarkan tabel di atas mahasiswa yang memperoleh nilai sangat baik sejumlah $28.13 \%$, nilai baik sejumlah $53.12 \%$, dan nilai sedang $18.75 \%$. Sedangkan yang mendapatkan nilai kurang 0\%. Dengan rata- rata keseluruhan mencapai 86.7 meningkat dari pre-assessment sebesar 50.5. Peningkatan itu juga dapat dilihat pada grafik berikut:

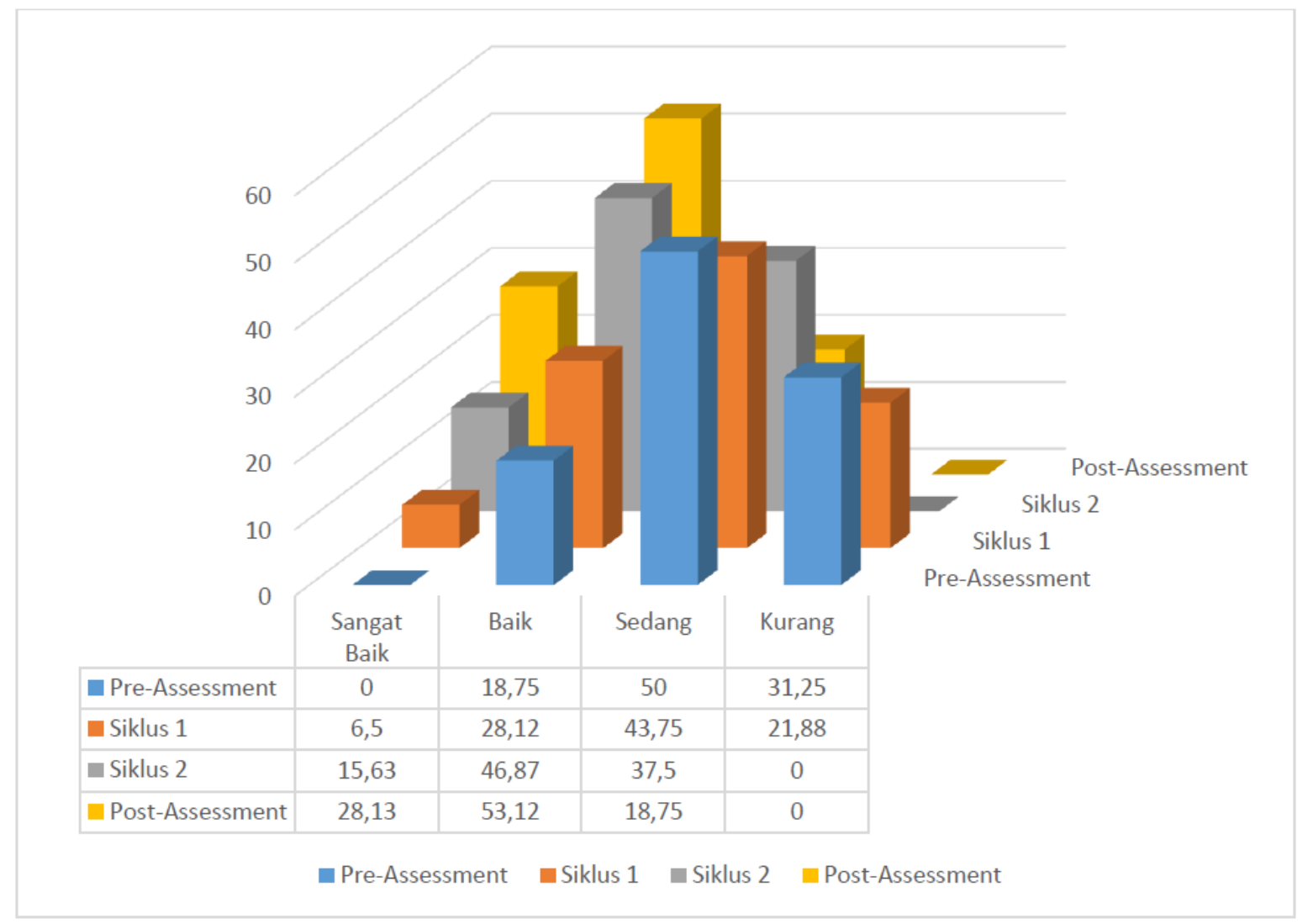

Gambar 1. Skor dari Pre-Assessment hingga Post-Assessment

Berdasarkan hasil berikut dapat disimpulkan bahwa setelah dilakukan penelitian tindakan kelas melalui siklus 1 dan 2 menggunakan strategi REAP, telah 
terjadi peningkatan kemampuan mahasiswa

PAI dalam menjawab pertanyaanpertanyaan secara argumentatif berdasarkan literasi yang tepat pada tema-tema Aqidah Akhlaq.

\section{KESIMPULAN}

Setelah dilakukan penelitian tindakan kelas pada mata kuliah Aqidah Akhlak ditemukan peningkatan rata-rata kelas di setiap tahapnya. Ketika PreAssessment ditemukan hasil rata-rata sebesar 50.5, meningkat pada siklus 1 sebesar 73.4 dan siklus 2 sebesar 82.6, kemudian hasil Post-Assessment didapatkan rata-rata kelas sebesar 86.7, peningkatan di setiap siklus diikuti dengan meningkatnya kemampuan mahasiswa dalam menelusuri literature dan menggunakannya dalam berargumentasi, meningkatnya keaktifan dalam diskusi, dan meningkatnya penyelesaian tugas yang diberikan. Berdasarkan hasil ini dapat disimpulkan bahwa penerapan strategi REAP dapat meningkatkan kemampuan literasi informasi mahasiswa calon guru. Hasil ini bisa dilihat dari perkembangan rata-rata kelas yang selalu meningkat di setiap tahapnya.

Penelitian ini masih belum sempurna, hanya focus pada penerapan
REAP pada materi Aqidah Akhlak saja, dimungkinkan penelitian lain yang menerapkan strategi REAP pada materi studi Islam lainnya seperti fiqih, sejarah Islam, tafsir dan lainnya.

\section{SARAN DAN UCAPAN TERIMA} KASIH

Ucapan terimakasih kami sampaikan kepada Universitas Muhammadiyah Sidoarjo yang bersedia menjadi sponsor bagi terlaksananya penelitian ini.

\section{DAFTAR PUSTAKA}

Al-Ghazali, Abu Hamid. 2005. Ihya' Ulumuddin. 1st ed. Beirut: Daar Ibnu Hazm.

Anthony V. Manzo. 1985. "Expansion Modules for the ReQuest, CAT, GRP, and REAP Reading/Study Procedures." Journal of Reading 28 (6): 498-502. http://www.jstor.org/stable/40029529. Cahyaningtyas, Andarini Permata, and Ali Mustadi. 2018. "The Effect of REAP Strategy on Reading Comprehension." In SHS Web of Conferences 42, 00014, 1-6.

https://doi.org/https://doi.org/10.1051/ shsconf/20184200014.

Ganggi, Roro Isyawati Permata. 2017. "Pendidikan Pemakai Di Perpustakaan Sebagai Upaya Pembentukan Pemustaka Yang Literasi Informasi." Khizanah Al-Hikmah: Jurnal Ilmu Perpustakaan, Informasi, Dan Kearsipan 5 (1): 121-28. https://doi.org/http://dx.doi.org/10.24 252/kah.v5ila11.

Ginanjar, M. Hidayat, and Nia Kurniawati. 2017. "Pembelajaran Akidah Akhlak 
Dan Korelasinya Dengan Peningkatan Akhlak Al-Karimah Peserta Didik (Studi Kasus Di Madrasah Aliyah Shoutul Mimbar Al-Islami Tenjolaya Bogor)." Jurnal Edukasi Islami Jurnal Pendidikan Islam 6 (12): 101-24.

Jabbar, Abdul. 1996. Sharh Ushuli LKhamsah. 3rd ed. Mesir: Maktabah Wahbah.

Manzo, Anthony, Ula Manzo, and Julie Jackson Albee. 2002. "IREAP: Improving Reading, Writing, and Thinking in the Wired Classroom." Journal of Adolescent \& Adult Literacy $46 \quad$ (1): 42-47. http://www.jstor.org/stable/40017504.

Manzo, Ula, and Anthony V. Manzo. 2010. "The Informal Reading-Thinking Inventory (IR-TI) The Informal Reading-Thinking Inventory: Assessment Formats for Discovering Typical \& Otherwise Unrecognized Reading \& Writing Needs - and Strengths." 2010. http://anthonymanzo.blogspot.com/2010/06/informa l-reading-thinking-inventory-ir.html.

Milles, Matthew B., A. Michael Huberman, and Johnny Saldana. 2014. Qualitative Data Analysis: A Method Sourcebook. 3rd ed. USA: SAGE Publications, Inc.

Nurhayati. 2014. "Akhlak Dan Hubungannya Dengan Aqidah Dalam Islam." Mudarrisuna 4 (2): 289-309.

Pattah, Sitti Husaebah. 2014. "Literasi Informasi Peningkatan Kompetensi Informasi Dalam Proses Pembelajaran." Jurnal Ilmu Perpustakaan \& Kearsipan Khizanah Al-Hikmah 2 (2): 117-28.

Renette, Rutela. 2016. "Using REAP (Read, Encode, Annotate, Ponder) In Teaching Reading." In Proceedings of the Fourth International Seminar on English Language and Teaching (ISELT-4), 278-82.

Setyowati, Lis. 2015. "Literasi Informasi Dilihat Dari Perspektif Modal Manusia." Libraria: Jurnal
Perpustakaan 3 (2): 232-46. https://doi.org/10.21043/libraria.v312. 1594.

Sukma, and Haryadi. 2016. "Keefektifan Strategi REAP Dan Request Dalam Pembelajaran Membaca Pemahaman Siswa Kelas VIII Smp." LingTera 3 (1): 99-111. https://doi.org/http://dx.doi.org/10.21 831/lt.v3i1.8476.

Zasrianita, Fera. 2016. "Using Of Reading, Encoding, Annotating, And Pondering (REAP) Technique To Improve Students' Reading Comprehension (A Classroom Action Research at Eighth Grade Students in MTSN 1 Kota Bengkulu in Academic Years 2016)." Ta'dib 19 (2): 147-64. 
